\title{
The Comparison of Smile Aesthetic of Males and Females Based on Buccal Corridor and Smile Arc
}

\author{
Perbandingan Estetika Senyum Antara Laki-Laki dan Perempuan \\ Berdasarkan Buccal Corridor dan Smile Arc
}

\author{
Lina Hadi, Puspa Maya Br Sembiring, Zulfan Muttaqin \\ Department of Orthodontics, Faculty of Dentistry, \\ Universitas Prima Indonesia, Medan, Indonesia \\ Corresponding author: linahadi@ unprimdn.ac.id
}

\begin{abstract}
In performing the orthodontic treatments, patients aim to improve their smile esthetical features which are influenced by the position, size, shape, and color of teeth. However, in recent decades, several aesthetical features that have been studied are buccal corridor, smile arc, incisor display, and gingival display. In this study, 32 subjects composed of 16 males and 16 females were photographed from the front-site by using a DSLR camera within smiling states. Smile arc and buccal corridor measurements were performed via Corel Draw 12 program. The extra broad and broad characteristics were found in male subjects which were $31.2 \%$ and $18.8 \%$ respectively, while the female subjects had a higher broad proportion of $43.7 \%$ and extra broad for $6.3 \%$. The smile arc features in male subjects were found were straight smile (34.4\%) and consonant smile (15.6\%), in contrast, the percentage of the female students had a higher consonant smile (31.3\%) than straight smile (18.8\%). This study confirmed similar findings regarding the domination of the buccal corridor broad in the female population, whereas the extra broad is dominated by males. By contrast, the smile arc consonant is dominated by females, while the straight feature is dominated by males.
\end{abstract}

Keywords: buccal corridor, orthodontic treatment, smile aesthetic, smile arc.

\begin{abstract}
Abstrak
Banyak pasien yang melakukan perawatan Ortodonti untuk meningkatkan estetika senyum, yang dipengaruhi oleh beberapa komponen seperti posisi, ukuran, bentuk, dan warna gigi. Namun dalam beberapa dekade terakhir, estetika senyum lain yang juga diteliti adalah buccal corridor, smile arc, incisor display, dan gingival display. Sebanyak 32 orang yang terdiri dari 16 laki-laki dan 16 perempuan, difoto menggunakan kamera DSLR pada posisi tersenyum dari arah frontal. Pengukuran smile arc dan buccal corridor menggunakan program corel draw 12. Hasil penelitian menunjukkan pada laki-laki,buccal corridor extra broadsebanyak 31,2\% dan broadsebanyak 18,8\%, pada siswa perempuan broadsebesar 43,7\% dan extra broadsebesar 6,3\%. Untuk smile arc pada laki-laki,straight smile ditemukan sebanyak $34,4 \%$ dan consonant smilesebanyak 15,6\%, pada siswa perempuan consonant smileditemukan sebesar $31,3 \%$ dan straight smile sebesar $18,8 \%$. Hasil penelitian ini sejalan dengan penelitian yang telah dilakukan sebelumnya oleh Sabri yang mana buccal corridor broad didominasi oleh perempuan dan extra broad oleh laki-laki. Smile arc consonant didominasi perempuan dan straight didominasi oleh laki-laki.
\end{abstract}

Kata kunci : buccalcorridor, perawatan ortodonti, estetika senyum, smile arc,

\section{INTRODUCTION}

Modern society has chosen orthodontic treatments in order to gain a beautiful smile and attractive facial features. ${ }^{1}$ The smile contributes to the physical appearances of people which are influenced by the lips, gingiva, and tooth as well as its arrangement. ${ }^{2}$
Basically, two types of smiles are determined, i.e. social and spontaneous smiles. The social smiles are commonly used to express greetings among people which are voluntarily performed, as well as expressing 
friendly smiles. On the other hand, spontaneous smiles generally occur during a pleasant situation. ${ }^{3}$

The diagnosis, treatments plan, and prognosis, contribute to orthodontics treatments. ${ }^{4}$ In optimizing the smile aesthetic features such as buccal corridor and smile arc, understanding in these features and practical skills of dentists is essentially required. According to a study conducted by Balani et al., in 2014, the most common features of buccal corridor characteristics found in male and female subjects were medium $(15 \%$ buccal corridor) and medium broad (10\% buccal corridor) respectively. Meanwhile, the smile arc in males was a straight smile, whereas the consonant smile is commonly found in female subjects. ${ }^{5}$

In orthodontics treatments, the smile aesthetical features contribute importantly to building confidence in a person. ${ }^{6}$ However, clinicians consider merely in angle malocclusion and cephalometric analysis such as dental and skeletal properties, so that frontal and soft tissue have not been considered ${ }^{7}$ The aesthetic of the smile has been slightly considered. ${ }^{8}$ Therefore, patients seek orthodontic treatments in the dental clinics to improve their aesthetical smiles. During the process of diagnosis and treatments, the dentist must monitor the teeth, soft tissue, and smile aesthetical characteristics. $^{9}$

This study aims to investigate the comparison of smiles between male and female students based on the smile arc and buccal corridor as an assessment and guidance for dentists in performing orthodontics treatments. ${ }^{10}$ The subjects involved in this study were students from SMA Negeri 4 Medan, and this study is expected as one of the clinical studies regarding orthodontic treatments in overcoming the malocclusion issues.

\section{MATERIALS AND METHODS}

This is an observational with the cross-sectional approach study. The research has been permitted by Local Educational Authority (Dinas Pendidikan Kota Medan), SMA Negeri 4 Medan, and the informed consent was explained to subjects which were then followed by photographic collection. As this study involved human subjects, the Ethical Committee of Health Research from Universitas Prima Indonesia has given permission for this study (027KEPK/ UNPRI/IX/2019).

Students who were in eleven grades in SMA Negeri 4 Medan, sub-district Sei Putih Tengah, District Medan Petisah, Medan were recruited. Then, 32 subjects with 16 male and 16 female students who have not been performing orthodontic treatments were obtained, and they also have a normal overjet-overbite condition, normal anterior of teeth anatomy, and no heavy crowded.

In taking the photographic data, subjects were instructed to stand up straight. The facial position towards directly to the camera lens by following the natural head position (NHP) feature, in which the Frankfurt plane is equal or parallel to the floor. The photos samples were taken in white background with a specified dimension (1.5 meters of height, and 1.2 meters of width). In order to reduce the reflection on the photographs, 0.75 meters of distance was set up. Thus, subjects were asked to create their social smile by pronouncing the word "cheese". Photographic shoots were taken from frontal direction to the nasolabial part, to the edge of the chin (1 meter). ${ }^{11}$

The measurement of smile components was performed via Corel Draw 12 software by drawing a line to determine the width of the buccal corridor and smile arc types. For the buccal corridor, the measured length was a distance formed by posterior teeth and lips angle, while the smile arc is the imaginary line formed via the contour of anterior cervical teeth from the maxilla and the contour of mandibula during the smiling act. Then, to determine the type of smile arc, the arch formed by mandibular lips was measured, and this measurement is based on the contact between mandibular lips to the edge of the maxillary incisor tooth. Meanwhile, the distance of the buccal corridor was calculated by using calipers to obtain the width and its classification. ${ }^{12}$ The statistical analysis was conducted via the Mann Whitney test to determine the comparison of male and female subjects.

\section{RESULTS}

From 32 subjects, it was found that 10 male subjects had extra broad characteristics of the buccal corridor $(31.2 \%)$, whereas the other six subjects had a broad feature $(18.8 \%)$. In contrast, the female subjects were dominated by the broad buccal corridor with 14 people $(43.7 \%)$, while the other had extra broad type (6.3\%) (Table 1). These findings have shown that the broad type of buccal corridor is more common than the extra broad type and the broad buccal corridor is mostly observed in female subjects. 
Table 1. Frequency distribution of aesthetical smile based on the buccal corridor.

\begin{tabular}{|c|c|c|c|c|c|c|c|}
\hline \multirow{3}{*}{$\begin{array}{l}\text { Classifi- } \\
\text { cation } \\
\text { Buccal } \\
\text { Corridor }\end{array}$} & \multirow{2}{*}{\multicolumn{2}{|c|}{ Male }} & \multirow{2}{*}{\multicolumn{2}{|c|}{ Female }} & \multirow{2}{*}{\multicolumn{2}{|c|}{ Total }} & \multirow{3}{*}{$\mathbf{P}$} \\
\hline & & & & & & & \\
\hline & n & $\%$ & $\mathrm{n}$ & $\%$ & $\mathrm{n}$ & $\%$ & \\
\hline Broad & 6 & 18.8 & 14 & $\begin{array}{l}43 \\
.7\end{array}$ & 20 & 62.5 & \multirow{2}{*}{$\begin{array}{c}<0.00 \\
4\end{array}$} \\
\hline $\begin{array}{l}\text { Extra } \\
\text { Broad }\end{array}$ & $\begin{array}{l}1 \\
0\end{array}$ & 31.2 & 2 & $\begin{array}{l}6 . \\
3\end{array}$ & 12 & 37.5 & \\
\hline
\end{tabular}

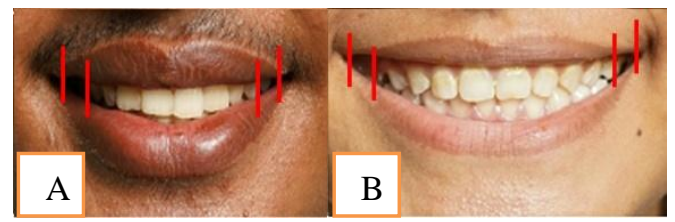

Figure 1. Extra Broad Buccal Corridor in (A) Male subjects, and (B) Female subjects

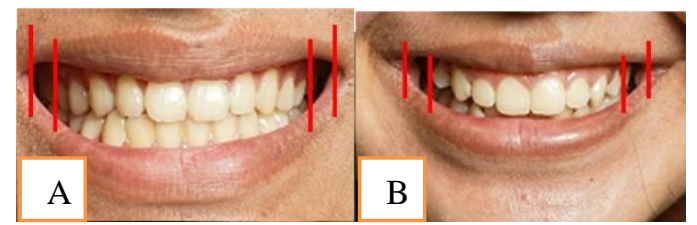

Figure 2. BroadBuccal Corridor in (A) Male subjects, and (B) Female subjects

The following Table 2 shows the distribution of smile arc types among subjects. 11 male subjects were observed to have a straight smile (34.4\%), whereas the other 5 subjects had a consonant smile (15.6\%). For female subjects, the most common types were found in the consonant smile with 10 people (31.3\%), while the straight smile was observed in the other six subjects (18.8\%). From these results, straight smile is dominated by male students, while the consonant smile is commonly found in female subjects.

Table 2. Frequency distribution of aesthetical smile based on Smile Arc.

\begin{tabular}{|c|c|c|c|c|c|c|c|}
\hline \multirow{3}{*}{$\begin{array}{l}\text { Classifi- } \\
\text { cation } \\
\text { Smile } \\
\text { Arc }\end{array}$} & \multirow{2}{*}{\multicolumn{2}{|c|}{ Male }} & \multirow{2}{*}{\multicolumn{2}{|c|}{ Female }} & \multirow{2}{*}{\multicolumn{2}{|c|}{ Total }} & \multirow{3}{*}{$\mathbf{P}$} \\
\hline & & & & & & & \\
\hline & $\mathbf{N}$ & $\%$ & $\mathbf{n}$ & $\%$ & $\mathbf{N}$ & $\%$ & \\
\hline $\begin{array}{l}\text { Consona } \\
\text { nt Smile }\end{array}$ & 5 & 15.6 & 10 & $\begin{array}{l}31 \\
.3 \\
\end{array}$ & 15 & 46.9 & \multirow{2}{*}{$\begin{array}{c}<0.08 \\
1\end{array}$} \\
\hline $\begin{array}{l}\text { Straight } \\
\text { Smile }\end{array}$ & 11 & 34.4 & 6 & $\begin{array}{c}18 \\
.8\end{array}$ & 17 & 53.1 & \\
\hline $\begin{array}{l}\text { Reverse } \\
\text { Smile }\end{array}$ & 0 & 0 & 0 & 0 & 0 & 0 & \\
\hline
\end{tabular}

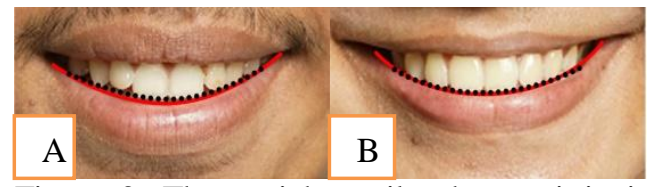

Figure 3. The straight smile characteristic in (A) male subjects and (B) female subjects

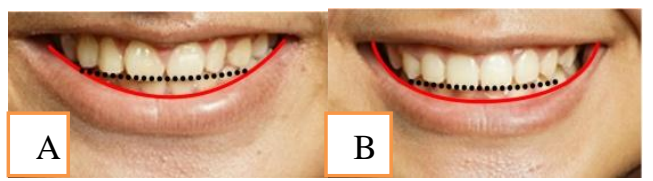

Figure 4. The photographic image of the consonant smile in (A) male subjects and (B) female subjects

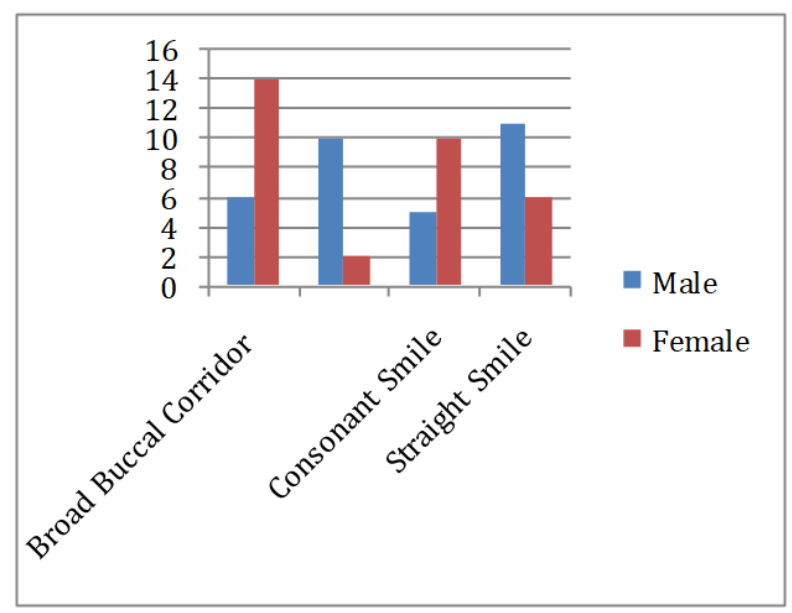

Figure 5. The Mann Whitney test $(\alpha=0.05)$ of the subjects based on the buccal corridor and smile arc.

The statistical analysis of Mann Whitney describes that the comparison of the buccal corridor in male and female subjects had a $p$-value of $p=0.004$, whereas the smile arc among all of them has no significant differences $(\mathrm{p}=0.081)$. The analysis also confirmed that the differences are in the extra broad and broad types, found dominantly in male and female subjects respectively.

The Mann Whitney test $(\alpha=0.05)$ has confirmed that no significant differences in smile arc were obtained among both male and female subjects $(\mathrm{p}=0.081)$. From a total of 32 subjects, 16 males and 16 females were recruited. From 16 male subjects, 10 subjects (31.2\%) had extra broad and 6 subjects $(18.8 \%)$ had broad features. On the other hand, from the 16 female subjects, 14 subjects (43.7\%) dominantly had broad, while the other 2 subjects had extra broad (6.3\%) buccal corridor. Our findings suggested different results than the study that were conducted by Balani; females 
had medium broad smile characteristics (38\%), and males had a medium broad smile $(62 \%)$.

The study results also showed that 11 male subjects had a straight smile (34.4\%), while 5 subjects had a consonant smile (15.6\%), and consonant smile was dominantly found in 10 female subjects (31.3\%), while the other six female subjects had a straight smile $(18.8 \%)$. A straight smile is generally found in male subjects, while the consonant smile is dominantly observed in female subjects. ${ }^{13}$ These results are in accordance to a study reported by Balani, in which a straight smile arc is commonly found in men, while the consonant smile arc was generally found in women. ${ }^{14}$

\section{DISCUSSION}

The disproportion of anterior and posterior teeth tends to cause the lowering of lips position. ${ }^{15}$ However, in male subjects who have tapered arch feature cause difficulties for them in positioning the mandibular lips to be located in upper maxillaryincisors. ${ }^{16}$ This also could cause the tooth movement which could be occurred outside the arch, and the labioversion and linguoversion tend to occur in mandibular during the completion of orthodontic treatments. ${ }^{17}$

\section{REFERENCES}

1. Ioi H, Nakata S, Counts AL. Effects of buccal corridors on smile esthetics in Japanese. Angle Orthod 2009; 79(4): 628-33.

2. Sachdeva K, Singla A, Mahajan V,Jaj H,Negi A. Esthetic and smile characteristics at rest and during smiling. J Orthod Soc 2012; 469(1): 17-25.

3. Musskopf ML, Rocha JM, Rösing CK. Perception of smile esthetics varies between patients and dental professionals when recession defects are present. Braz Dent J 2013; 24(4): 385-90.

4. Câmara CA. Estética em Ortodontia. Dental Press J Orthod 2010; 15(1): 118-31.

5. Jain U,Kallury A, Singh G,Balani R. Evaluation of smile esthetics in central India. APOS Trends Orthod 2012; 4(6): 163-7.

6. Sabri R.The eight components of abalanced smile. J Clin Orthod 2005; 39(3): 155-67.

7. Parekh DH. Smile-a diagnostic tool: Photographic analysis in adult Gujarati population. IOSR J Dent Med Sci 2013; 12(4): 39-46.

8. Khan R, Samant PS, Singh AR, Chauhan R. Smile designing. Int J Curr Res 2018;10(2): 68989-91.

9. Singla S, Lehl G. Smile analysis in orthodontics. Indian J Oral Sci 2014; 5(2): 50-1.
Whilst, the consonant smile can be used as the basic determiner of an ideal smile. However, incomplete evaluation during the orthodontic treatments could cause changes in a straight smile or even reverse smile. $^{18}$

In performing the orthodontic treatments, the height of the bracket has different usage when it is applied to straight smile arc and consonant features. In a straight smile arc, the applying of bracket that is near to the cervical area could give more consonant characterristics to the smile or vice versa. ${ }^{19}$

During the orthodontic treatments, the change of smile components is occurred. ${ }^{20}$ For instance, the large buccal corridor can be reduced by expanding the maxillary arch to patients with transversal maxillary deficiency to improve aesthetical smile. ${ }^{21}$ However, it is not recommended to expand the normal maxillary arch for the reduction of the buccal corridor only. The above conditions must be clinically observed during the treatment plan. ${ }^{11}$

In conclusion, there is a significant difference of the buccal corridor found between male and female subjects, and no significant differences were found in smile arc types. Thus, gender is essentially required to be considered during orthodontic treatments.

10. Yang IH, Nahm DS, Baek SH. Which hard and soft tissue factors relate with the amount of buccal corridor space during smiling. Angle Orthod 2008; 78(1): 511.

11. Nurfitrah A,Christnawati C, Alhasyimi AA. Comparison of esthetic smile perceptions among male and female Indonesian dental students relating to the buccal corridors of a smile. Dent J 2018; 50(3): 127-30.

12. Goenharto $\mathrm{S}$. Intra dan ekstra-oral fotografi untuk rekaman orthodontic. Rec Libr J 2016; 2(2): 152-61.

13. Tarvade SAG. Smile analysis. ArticInt J Contemp Dent Med Rev 2015; 4(4): 12-5.

14. McLeod C, Fields HW,Hechter F, Wiltshire W, Rody W, Christensen J. Esthetics and smile characteristics evaluated by laypersons. Angle Orthod 2011; 81(2): 198-205.

15. Nascimento DC, Santos ER, Machado AWL, Bittencourt MAV. Influence of buccal corridor dimension on smile esthetics. Dental Press J Orthod 2012; 17(5): 145-50.

16. Roden-Johnson D, Gallerano R, English J. The effects of buccal corridor spaces and arch form on smile esthetics. AmJ Orthod Dentofac Orthop 2004; 127(3): 343-50. 
17. Tüzgiray YB, Kaya B. Factors affecting smile esthetics. Turkish J Orthod 2013; 26(1): 58-64.

18. Martin AJ, Buschang PH,Boley JC, Taylor RW, McKinney TW. The impact of buccal corridors on smile attractiveness. J Orthod 2007; 29(5): 530-7.

19. Geld P van der, Oosterveld P, Bergé SJ,KuijpersJagtman AM. Tooth display and lip position during spontaneous and posed smiling in adults. Acta Odontol Scand 2008; 66(4): 207-13.

20. Mclaren PEA, Culp L. Smile analysis and photoshop smile design technique. J Cosmet Dent 2013; 29(1): $1-10$.

21. Trisnawaty N. Buccal corridor yang lebih menarik pada estetik senyum. Dent J 2017; 4(1): 1-6. 